\title{
The Gender Implications of Large-Scale Land Deals
}

\author{
Julia Behrman, Ruth Meinzen-Dick, and Agnes R. Quisumbing
}

IFPRI Policy Brief 17 • April 2011

W hether viewed as "land grabs" or as agricultural investment for development, large-scale land deals by investors in developing countries are generating considerable attention. However, investors, policymakers, officials, and other key stakeholders have paid little attention to a dimension of these deals essential to truly understanding their impact: gender. It is easy to laud outside investment in agriculture, or to deride land deals and the accompanying processes as bad or unfair, without looking at the benefits and costs to local men and women. The results of land deals depend in part on the prior rights and responsibilities of women and men and in part on how the land deal's implementation perpetuates, improves, or distorts these rights and responsibilities.

A wide-ranging body of evidence forms a clear rationale for prioritizing gender issues in agriculture. ${ }^{1}$ Households often do not act as a single unit when allocating food and nonfood resources, which means all household members may not benefit from providing the male household head with more income. ${ }^{2}$ Evidence shows that improvements in household agricultural productivity, food security, and nutrition must address women's needs because, in many parts of the world, women are more likely than men to spend the income they control on food, healthcare, and their children's education. ${ }^{3}$ Conversely, land deals can reduce the welfare of women and their families, even if men's income increases. Land-related investments promoted in the name of "rural development" will miss their mark unless the many actors involved-including national and local governments, nongovernmental organizations (NGOs), the research community, and investors-recognize and address the needs of women as well as men.

\section{Land Deals through a Gendered Lens}

Land deals take many forms and occur in various contexts. The land in question may be privately owned-as is the case in much of Latin America and Asia-or customarily held by local tribes and clans and formally owned by the state-as is the norm in much of Sub-Saharan Africa. Depending on who formally owns the land under consideration, national government authorities, local elite, or local farmers' associations or communes may represent the seller or lessor. The investor may be any group of governments, corporations, or individual actors from within a country or other governments, private investment companies, or individual investors from outside the country. The actual deal may take the form of a shortterm lease (15-20 years), a long-term lease (50-99 years), or a sale. The scale of the deal can vary greatly, with estimates ranging between 10,000 and 500,000 hectares. ${ }^{4}$ The deal could result in a large-scale farm that hires employees or a contract-farming agree- ment with local farmers. In spite of these differences, a number of common potential gender impacts and issues exist throughout a land deal's various stages.

\section{Situation Prior to Acquisition}

Prior to any acquisition, one must understand who in the community has formal or informal land ownership and use rights and how gender, age, marital status, ethnicity, or other distinguishing factors may influence these rights. Poor rural women face disadvantages in land access and ownership in both customary and formal titled systems, even prior to a deal. In contexts where customary land tenure dominates-such as Sub-Saharan Africa-most women gain access to land only through a husband or male family member. In contexts where formal titles are common-such as Latin America-very few women hold titles and even fewer own large-scale enterprises. Land deals will likely exacerbate these existing gender disparities in land access and ownership. In contexts where titling is prevalent, if the title has only the male household head's name, a woman may not have any say regarding its sale or lease, even if they jointly acquired the land or if the woman uses some portion of the land for productive purposes or both. In contexts where customary land rights dominate, evidence suggests that privatization concentrates land in the hands of those who can successfully assert ownership, such as community leaders and male household heads, often to the detriment of poor rural women's access and use rights. ${ }^{5}$ In addition, common lands that women depend on for collecting firewood, water, fodder, and medicinal plants often have the most insecure tenure-governments may even designate them as "wastelands"-and are therefore most likely to be given up for outside investment. 6

\section{Contract Negotiations}

A consultation and negotiation process typically initiates land acquisition, ultimately leading to a contract that formally lays out the deal's terms. The great diversity in how this process plays out and the extent to which the deal makers take local perspectives into account has important implications for men and women. During formal and informal consultations and negotiations, local men and women may not be equally represented due to legal or social restrictions. For example, in a case study of oil palm plantations in Indonesia, companies coming into the district to set up the plantations often reinforced-if not exacerbated-existing patriarchal norms and gender disparities by relying solely on male community leaders to help sign up smallholder farmers, disseminate information, and resolve conflicts. ${ }^{7}$ The companies left women out of initial 
community consultations precisely because the women did not have visible community leadership roles.

\section{Employment}

Local men and women may not benefit equally from new employment or income generation opportunities, which are most commonly cited as the main benefits of large-scale farming. It is important to know if men and women will be hired equally to work as laborers because in some contexts investors or local communities assume that wage labor is largely or exclusively for men. Also, many communities-especially rural ones with limited resourceshave a history of prioritizing boys' education over girls', resulting in potential gender disparities in human capital. ${ }^{8}$ These disparities may relegate women to lower-skill positions. When jobs require formal education, making better provision for girls' schooling may be the only thing that can be done to promote equality. However, it is worth looking at whether the jobs really require formal education, or whether adult education can provide the necessary skill upgrades for women. Also, women workers, who have the added burden of balancing childcare and work, need adequate childcare facilities in order to participate in newly created employment.

Rather than drawing from the local population to fill the labor force needed to run large-scale farms, investors may decide to import their own workers from other countries to fill lower-level or managerial positions or both. This could be damaging for local men and women who would likely be relegated to peripheral jobs or entirely excluded from large-scale farm employment opportunities. Managers from other countries may bring their own views about the role women can or should play in agricultural production, which may not be compatible with existing norms. In the production of high-value crops and biofuels, and in other types of commercial agriculture, there is also a trend toward the "gendering" of tasks: women are perceived as more "nimble" and assigned tasks such as pruning, spraying, thinning, and tying, thereby excluding them from better-paying, less strenuous, or less dangerous activities. ${ }^{9}$

The introduction of mechanized production methods may be a mixed blessing for both local men and women. While exclusive reliance on mechanized methods can limit employment opportunities, some mixed labor and mechanized systems can help women by eliminating the most physically strenuous part of the process. ${ }^{10}$ Ultimately, whether or not men and women benefit from mechanization and other new technologies depends on whether there are concurrent increases in labor demand, opportunities for technology application outside the realm of the investment project, and targeting of technologies.

Contract farming agreements with local farmers give investors an alternative to the establishment of a large-scale farm. Under contract farming agreements, the farmer remains in control of the land and agrees to provide a given quantity and quality of a product within a specified timeframe in exchange for the investor agreeing either to purchase the harvest at a set price or to provide a fixed percentage of the harvest to the farmer as rent. Contract farming is often posited as a more equitable option for smallholder farmers because it allows them to retain control over and benefit from their land and labor. However, the gender equitability of contract farming arrangements depends on a variety of factors, including who in the household receives the compensation for contracted production and whose crops will be displaced by new production. In some instances investors make the contract only with a male household head, although many male and female family members provide labor. ${ }^{11}$ Evidence shows that some men in contract farming systems have taken over women's crops as the crops become more profitable. ${ }^{12}$ On the other hand, when investors deliberately target female participants, provide training and inputs to female farmers, and promote enterprises appropriate for women, contract farming can be profitable for women. ${ }^{13}$

\section{Environmental Impacts}

Both large-scale and contract farming systems can create environmental impacts that will affect local men and women. For example, monocropping eliminates biodiversity, namely wild plants used by local women and men for food or medicine. The use of agrochemicals releases pollutants that may reduce local soil and water quality. These pollutants may seriously affect the local community's health, particularly if investors do not adopt proper protection or cleaning methods. Evidence indicates that those who control the farms often do not provide workers, especially women workers, with adequate protective gear or proper training on agrochemicals, and there is little monitoring of the effects on worker health, particularly women's reproductive health. ${ }^{14}$ Furthermore, the need for water to irrigate large-scale agricultural production for staple crops or biofuels will likely compete with the need for water for food production, livestock, and domestic consumption. Women, who are typically responsible for domestic chores, including collecting water, fuel, and fodder, may experience environmental impacts most directly.

\section{Crop Production}

Another key issue is what type of crops will be planted on the land in question, and how those crops will be divided between home consumption, local markets, and exports. Staple crops-such as rice, maize, and millet-are usually planted with the intent of export to investor countries that lack the land and water resources necessary for domestic production. In some contexts, all of the crops produced will be exported to the investor's country, which can be detrimental to local food security, particularly if it diverts local labor from subsistence farming to wage labor. In some instances, a portion of the product may be sold in local markets or given to local laborers. In other cases local populations hired as laborers may retain a percentage of the crop yield as a rent or payment for labor. The availability of staple crops, along with crops rich in important nutrients and vitamins, is particularly important to women who act as the guardians of household food security. Other land deals are for production of biofuels, including bioethanol and biodiesel, which are increasingly produced in developing countries and sold on the global market as an alternative to fossil fuels. Exclusive biofuel production can be detrimental for local food security because land and water will be diverted from food production and livestock grazing to biofuel production. ${ }^{15}$ Lands primarily used by women are regularly converted for biofuel production, which might contribute to women's socioeconomic marginalization. 


\section{Ancillary Services}

As part of a land deal investors often provide ancillary services. Targeted investments in nonagricultural infrastructure, such as construction of roads, rail links, or port facilities, will mutually benefit investors looking to improve supply chains and members of the local population with existing social and financial mobility. Some investors also finance primary schools, hospitals, clinics, or other local public goods beneficial to local populations. Investments of this type may particularly benefit women of reproductive age or women responsible for overseeing the schooling and healthcare of their children. On the other hand, company stores can become a source of indebtedness, thus perpetuating cycles of poverty, unless the terms of trade and credit are favorable.

\section{Responsibilities of Key Actors}

Properly executed large-scale land deals that give appropriate attention to gender dimensions can provide opportunities for both women and men through the introduction of new employment and income generation opportunities, new technologies, and new services. Appropriately designed land deals may even aid in increasing the gender-equitable distribution of local resources. Investors also stand to benefit from land deals that take into account the full range of skills, labor potential, and knowledge of local women and men. But if land deals fail to address local contextual issues and gender dimensions, investments will at best perpetuate existing gender inequalities and at worst contribute to increased poverty and conflict. Investors will lose out if their plan ignores the labor potential of half the population or causes community unrest.

Large-scale land deals are not isolated issues, but are linked to many interrelated policies, including land reform and certification, agricultural investments, and trade policy, as well as legislation to promote gender equality, attract potential investors, and regulate investments. The challenge is to see how the policy framework surrounds agricultural development and influences land deals, as well as how gender can become an integral part of the framework, rather than an afterthought.

- Land reform and certification can help secure existing users' land rights and thereby ensure that both women and men will benefit from the land's sale or lease. Including the names (and photos) of both husband and wife, as was done in Ethiopia, will help to secure the land against expropriation by one spouse.

- Agricultural research and infrastructure investments in developing countries, coupled with private investment to improve input supply, processing, and marketing, could increase the productivity of existing male and female land users without the surrender of their land to outside investors.

- Countries can ensure that trade and investment policies, which affect the profitability of land deals and the incentives for foreign investors to acquire land as a tool for obtaining food, are not biased against existing local male and female producers.

- Legislation to promote gender equality-for example, in inheritance or in the actions of local governments-can strengthen women's voice and bargaining power, making government services such as extension and land registration more gender equitable.

\section{The International Community}

The international development, policy, and research community has the opportunity to set out consistent expectations for land deals. International standards and guidelines on land deals should include provisions promoting gender equity in negotiations, contracts, and employment. An international governance body could monitor execution of land deals or rank investors' past performance across a variety of indicators-including attention to gender. Provisions, investor rankings, and other relevant information should be publicized, for example, with a common website, to which investors, governments, nongovernmental organizations (NGOs), and communities could refer.

In addition, the international research community plays a valuable role in addressing critical knowledge gaps of donors, investors, and governments through research on gendered effects of land deals. Likewise, the international development community can support capacity strengthening for governments and communities to include gender issues in negotiation and implementation of land deals. Yet, limited empirical evidence exists on the differential effect large-scale land deals have on men and women and on consequences for rural poverty. Future research needs to include gender disaggregated data on time use and level of and control over production and income prior to acquisition, and should monitor how these outcomes change over the course of the land deal. Detailed case studies based on solid field research would provide a better understanding of the diverse contexts in which land deals take place.

\section{National Governments}

National governments can strengthen the property rights of communities by recognizing customary tenure and common property so that land is not given to investors without the consent of local users. At the same time, governments should ensure that women can hold land and are included in any land titling or certification programs, such as through joint landholdings and spousal consent clauses. National governments can also promote a fair labor market and employment regulations through the development or strengthening of regulations to ensure the health and safety of agricultural workers and the prevention of gender-based discrimination (including provision for maternity leave). When conducting negotiations with investors, national governments should consider investors' past actions and performance when authorizing deals.

National governments need to require that potential investors hold in-depth, interactive, and monitored meetings with women and men. National governments must also strictly enforce labor lawsincluding laws concerning health and safety-and promises to invest in public services and communities.

\section{Local Governments, Communities, and Civil Society}

Local governments, NGOs, communities, and civil society organizations must do their part in making land deals gender equitable by recognizing traditional land rights of male and female land users (not just male household heads), particularly when conducting land certification. Local governments or community groups involved in 
land-deal negotiations should include both women and men in consultation and negotiation processes. At the same time, local NGOs, community-based organizations, or community groups should focus on capacity strengthening by offering legal literacy courses or other relevant training on property rights and contracts in order to prepare women to participate in negotiations and assert their rights. These groups should also provide education opportunities that will qualify women and girls for better jobs at higher management levels.

\section{Domestic and International Investors}

To develop gender-equitable land deals, investors must disseminate information on the acquisition process to male and female community members through information channels that reach a wide audience (rather than dispersing information solely through male community leaders). Likewise, investors need to consult with local men and women on short- and long-term goals, wants, and needs throughout the acquisition process. Because the preexisting situation will largely shape how land deals affect communities, investors need to develop an effective monitoring and evaluation system: baseline (prior to acquisition) gender-disaggregated data on time use, production, income generation, and control over income should be used to monitor at regular intervals how these outcomes change over time, and investors should conduct long-term follow-up to assess effects that may not be apparent in the short term.

After a deal has been made, investors need to continue to work for gender equity. Contract-farming investors should target female and male farmers (not just male household heads) and provide appropriate extension services to ensure they properly inform men and women about new technologies and agricultural information.
When land deals lead to the development of large-scale farms, investors need to take a number of measures to ensure the gender equity of labor. These include hiring local women and men to work as wage laborers in fixed-contract positions (rather than only as temporary or casual workers); assigning male and female employees to tasks based on appropriate assessment of task requirements and abilities rather than stereotypes about "male" and "female" jobs; and including promotion opportunities for talented local male and female employees. In addition, investors should provide appropriate safety equipment for all activities involving potentially hazardous materials. They should also provide childcare facilities to increase the probability of women's participation in the labor force, to improve women's mobility, and to minimize the incidences of child labor. Providing other community services, such as healthcare and education, which benefit marginalized groups-including womenthe most, can also help to produce gender equitable land deals. New development should not decrease water quantity or quality for local users; if it does, investors should provide an improved water supply (through boreholes or piped-water systems, for example). Ensuring gender equity in land deals may seem to increase time and transaction costs in the short run, but it is imperative to the overall success of land deals for all actors involved.

\section{Concluding Remarks}

Prioritizing gender issues benefits not just local men, women, and children, but also the investors. More gender equality may lead to greater reductions in poverty and increases in agricultural productivity. To see these results, many different actors must work together to create an environment with the potential for gender equity.

\footnotetext{
1 For a more detailed examination of this body of evidence, please see the discussion paper on which this brief is based: J. Behrman, R. Meinzen-Dick, and

A. R. Quisumbing, The Gender Implications of Large-Scale Land Deals, IFPRI Discussion Paper 1056 (Washington, DC: International Food Policy Research Institute, 2011).

2 A. R. Quisumbing, ed. Household Decisions, Gender, and Development: A Synthesis of Recent Research, (Washington, DC: International Food Policy Research Institute, 2003).

3 L. C. Smith, U. Ramakrishan, A. Ndjaye, L. Haddad, and R. Martorell, The Importance of Women's Status for Child Nutrition in Developing Countries, Research Report 131 (Washington, DC: International Food Policy Research Institute, 2002).

4 FAO (Food and Agriculture Organization of the United Nations), International Investment in Developing Country Agriculture-What Are the Issues? (Rome: FAO, 2009).

5 S. Lastarria-Cornhiel, "Impact of Privatization on Gender and Property Rights in Africa," World Development 25, no. 8 (1997): $1317-1333$.

6 A. Rossi and Y. Lambrou, Gender and Equity Issues in Liquid Biofuels Production: Minimizing the Risks to Maximize the Opportunities (Rome: Food and Agriculture Organization of the United Nations, 2008).

7 Julia and B. White, Agro-Fuels, Enclosure and Incorporation: Gendered Politics of Oil Palm Expansion in a Dayak Hibun Community in West Kalimantan, Working Paper (Rotterdam, The Netherlands: International Institute of Social Studies, 2010).

8 S. Klausen, "Low Schooling for Girls, Slower Growth for All? Cross-Country Evidence on the Effect of Gender Inequality in Education on Economic Development," World Bank Economic Review 16, no. 3 (2002): 345-373.

9 C. Dolan and K. Sorby, Gender and Employment in High-Value Agriculture Industries, Agriculture and Rural Development Working Paper 7 (Washington, DC: World Bank, 2003). 10 R. Anker, Gender and Jobs: Sex Segregation of Occupations in the World (Geneva: International Labour Organization, 1998).

11 L. Raynolds, "Wages for Wives: Renegotiating Gender and Production Relations in Contract Farming in the Dominican Republic," World Development 30, no. 5 (2002): 783-798.

12 C. Dolan and K. Sutherland, Gender and Employment in the Kenya Horticulture Value Chain, Globalization and Poverty Working Paper (Norwich, UK: Overseas Development Group, University of East Anglia, 2002).

13 L. M. Bangwe and B. van Koppen, Zambian Smallholder Out Growers in Irrigated Agriculture, Working Paper (Colombo, Sri Lanka, and Lusaka, Zambia: International Water Management Institute and Farming Systems Association of Zambia, 2010).

14 R. Loewenson, "Occupational Safety and Health for Women Workers in Agriculture," Labour Education 1-2, no. 118-119: (2000) 35-45.

15 UN-Energy, Sustainable Bioenergy: A Framework for Decision Makers, (Rome: UN, 2007).
}

Julia Behrman is a senior research assistant in the Poverty, Health, and Nutrition Division, Ruth Meinzen-Dick is a senior research fellow in the Environment and Production Technology Division, and Agnes R. Quisumbing is a senior research fellow in the Poverty, Health, and Nutrition Division at the International Food Policy Research Institute, Washington, DC. 